\title{
Relationship between Occupational Stress, 5-HT2A Receptor Polymorphisms and Mental Health in Petroleum Workers in the Xinjiang Arid Desert: A Cross-Sectional Study
}

\author{
Ting Jiang ${ }^{1,+}$, Hua Ge ${ }^{1,+}$, Jian Sun ${ }^{2,+}$, Rong Li ${ }^{1}$, Rui Han ${ }^{3}$ and Jiwen Liu ${ }^{1, *}$ \\ 1 Department of Public Health, Xinjiang Medical University, Urumqi 830011, China; jt5583@126.com (T.J.); \\ gehua2710@sina.com (H.G.); lurong_128@126.com (R.L.) \\ 2 The Sixth Affiliated Hospital of Xinjiang Medical University, Urumqi 830011, China; sjt3997@163.com \\ 3 The First Affiliated Hospital, School of Medicine, Shihezi University, Shihezi 832008, China; \\ shihaohua789@163.com \\ * Correspondence: liujiwen@xjmu.edu.cn; Tel.: +86-991-436-5004; Fax: +86-21-6408-5875 \\ + These authors contributed equally to this work.
}

Academic Editor: William A. Toscano

Received: 22 January 2017; Accepted: 7 April 2017; Published: 10 April 2017

\begin{abstract}
At present, there is growing interest in research examining the relationship between occupational stress and mental health. Owing to the socioeconomic impact of occupational stress and the unique environment of petroleum workers in Xinjiang, a cross-sectional study was carried out between April and December 2015 to investigate the relationship between occupational stress, 5-hydroxytryptamine receptor (5-HTR2A) genotype, and mental health. A total of 1485 workers were selected. The Symptom Checklist 90 was used to assess nine classes of psychological symptoms. Work-related stressors were evaluated using the Occupational Stress Inventory-Revised Edition. Levels of 5-HTR2A (the T102C and A-1438G single nucleotide polymorphism in the 5-HTR2A gene) were measured by polymerase chain reaction and restriction fragment length polymorphism (PCR-RFLP). The findings of the present study revealed a high prevalence rate of mental health problems $(40.29 \%)$ in petroleum workers stationed in the arid desert, and suggested a strong correlation between occupational stress and mental health. The TC and CC genotype of T102C were found to be protective factors against mental health problems (odds ratio $(\mathrm{OR})=0.455,95 \%$ confidence interval $(\mathrm{CI}):=0.269-0.771$, odds ratio $(\mathrm{OR})=0.340,95 \%$ confidence interval $(\mathrm{CI}): 0.162-0.716)$. AG and GG genotype of A-1438G [odds ratio (OR) $1=2.729$, 95\% confidence interval (CI): 1.433-5.195; odds ratio (OR) $2=2.480,95 \%$ confidence interval (CI): 1.221-5.037] were revealed as risk factors. These data provide evidence that occupational stress and 5-HTR2A gene polymorphism contributes to the incidence of mental health problems.
\end{abstract}

Keywords: 5-HT2RA; mental health; occupational stress; petroleum workers

\section{Introduction}

Due to the rapid development of society, science, technology, and the organization of the labour process as well as changes to ways of life, occupational stress has been shown to be an important social determinant of health that negatively impacts workers [1,2]. Psychological health is "a state of wellbeing in which the individual realizes his or her own abilities, can cope with the normal stresses of life, can work productively and fruitfully, and is able to make a contribution to his or her community" [3]. There is increased interest in research examining the relationship between occupational stress and mental health [4-8]. 
Some research has shown that stress significantly contributes to the development of mental illness $[9,10]$, and that the higher the levels of stress, the higher the incidence of mental illness [11]. Furthermore, psychological distress is recognized as a strong predictor of the onset of a major depressive episode [12]. An et al. [13] have also highlighted that if there is no reduction in severe stressors, a further deterioration in mental health will ensue.

Individuals exhibit a broad range of nervous system responses which may be partly attributed to genetic factors. Adrenal responses to stress-reflecting deviations from normal physiological or psychological set points-demonstrate area major function of the hypothalamic-pituitary-adrenal (HPA) axis in general adaptation syndrome [14]. This axis is one of the body's primary hormonal systems for responding to stress and the first to respond to social stressors [15]. Moreover, the basal activity and reactivity of the hypothalamic-pituitary-adrenal (HPA) axis is modulated by and in turn modulates neurotransmitters such as serotonin (5-hydroxytryptamine, 5-HT) [16-18]. The 5HTR2A gene is located onchromosome 13 (13q14-q21); it spans $20 \mathrm{~kb}$ and contains 3 exons; more than 200 SNPs have been identified along the gene $[19,20]$. Genetics can predict 5-HT system activation, given its relationship to strain [21]. 5-HT is an important monoamine neurotransmitter in the body that may mediate anxiety, depression, and other related mood disorders. Previous studies have suggested an association between 5-HT receptor gene polymorphism and depression [22-24]. Mainly, the polymorphisms A-1438G (rs6311), and T102C (rs6313) have been studied in relation to mental health. Mental health may also be correlated with T102C and A-1438G gene polymorphism in the 5-HTR2A [25,26].

Petroleum workers employed by the Xinjiang Field Petroleum Administration Bureau are a unique category of professionals. These employees have long working hours, engage in shift work every six months, and their tasks are very arduous. Workplaces are situated in arid deserts where employees are subjected to isolation, extreme weather, and heavy sand storms. Several studies have reported that mental and physical health are affected by natural conditions including the monotonous lifestyle of arid deserts and other harsh environments $[27,28]$. Due to the socioeconomic impact of occupational stress [29], the majority of research studies have focused on white-collar workers $[30,31]$ although few studies have examined the relationship between occupational stress, 5-HTR2A polymorphism, and mental health in petroleum workers stationed in arid deserts [32,33]. This research conducted a cross-sectional study of petroleum workers in Xinjiang to investigate: (1) the relationship between occupational stress and mental health; and (2) the relationship between 5-HTR2A polymorphism and mental health.

\section{Methods}

\subsection{Participants}

This current research was a cross sectional study which performed between April to December 2015. In 2015, Petroleum workers were selected from the Xinjiang Petroleum Administration Bureau of China National Petroleum Corporation in Karamay City, Xinjiang Province, China. Using a three-stage stratified sampling method, five operating areas, five production factories, and five exploration and development companies were selected based on the Chinese Standard Industrial Classification of the nature of the companies. Then, based on the size of the companies, we randomly selected two large company ( $>1000$ workers) and one small company ( $<1000$ workers) from selected operating areas; one large company ( $>600$ workers) and one small company ( $<600$ workers) from selected production factories; and one large ( $>200$ workers) and two small ( $<200$ workers) exploration and development companies. Finally, for operating areas, we selected 600 workers from large companies, 345 from small companies; for production factories, we selected 390 and 160 workers from large and small companies, respectively; for exploration and development companies, we selected 170 and 90 workers from large and small companies, respectively. Workers were selected by applying computer-generated random numbers to the managers' lists of employees. In the course of their work, the participants engaged in 
geophysical prospecting, drilling, testing, downhole operation, transferring oil, etc. All participants have a period of employment longer than one year. Those who had a prior history of mental illness such as depression, anxiety disorder, bipolar disorder, schizophrenia etc., were excluded from the study. All participants provided written informed consent. Ultimately, 1485 workers were selected to participate in this current research, and their demographic and occupational data we obtained from worker information system, which was approved by Xinjiang Petroleum Administration Bureau of China National Petroleum Corporation. This study was approved by the Ethics Committee of the First Teaching Hospital at Xinjiang Medical University, Urumqi, China. (Identification Code: 2015008).

\subsection{The Self-Report Symptom Inventory: Symptom Checklist 90 Revised (SCL-90)}

Mental health was measured using the Chinese SCL-90-R [34]. The SCL-90-R is a 90-item self-report symptom inventory, multidimensional in nature, and oriented toward the measurement of psychopathology. Each of the 90 items is rated on a 5-point scale of distress, ranging from 1 to 5 was used: $1=$ no, $2=$ mild, $3=$ moderate, $4=$ quite serious, $5=$ serious. The SCL- $90-R$ is scored on the following nine primary symptom dimensions: somatisation; obsessive-compulsive; interpersonal sensitivity; anger-hostility; depression; anxiety; paranoid ideation; phobic anxiety; and psychoticism [35]. Higher scores of SCL-90 indicate more severe psychological symptoms which may result in higher prevalence of workers with mental health problems depending on the cut-off value, A total score exceeding 160 points on the SCL-90 was used to measure the presence of mental health problems [36].

\subsection{Occupational Stress Inventory Revised Edition (OSI-R)}

Occupational Stress were measured using the Occupational Role Questionnaire subscales from the Chinese version of the OSI-R [37]. The OSI-R is a reliable and valid method for measuring stressors in different occupational populations throughout China [38,39]. The OSI-R consists of three subscales: Occupational Roles Questionnaire (ORQ), Personal Strain Questionnaire (PSQ), and Personal Resources Questionnaire (PRQ). The ORQ included six subscales (i.e., Role Overload, Role Insufficiency, Role Ambiguity, Role Boundary, Responsibility, and Physical Environment) and was used to assess work-related stressors. The PSQ included four subscales (i.e., Vocational Strain, Psychological Strain, Interpersonal Strain, and Physical Strain) and was used to assess levels of personal strain. The PRQ included four subscales (i.e., Recreation, Self-Care, Social Support, and Rational Coping) and was used to assess coping resources. A scale ranging from 1 to 5 was used to assess occupational stress. While higher scores for the ORQ and PSQ indicated higher stress levels, higher scores for the PRQ corresponded with lower stress levels and a greater ability to cope with stress.

\subsection{Quality Control of Questionnaires}

All questionnaires were provided to participants and immediately collected in the activity centre. The questionnaires were completed anonymously within $15 \mathrm{~min}$. As the initialization of the survey, participants are instructed to be aware of how they should complete questionnaires, realize the significance of the study, and ensure that the participants cooperated well so that they could truthfully and accurately complete each questionnaire item. Throughout this time, two experienced psychologists and two officers engaged with participants to ensure cooperation with the research team as well as to safeguard the authenticity and efficacy of the questionnaire responses. During the survey, and after having recorded the results, the completed questionnaires were comprehensively reviewed by two researchers in order to examine any uncertainty concerning the responses, to correct errors, and to address any omissions in questionnaire responses.

\subsection{Genetic Biomarkers}

Thirty percent of the petroleum workers who had correctly completed their questionnaires were selected from the mental health problems group through the use of random sampling to determine the 
polymorphisms of 5-HTR2A, and normal group which is determined as normal condition depending on SCL-90 matched with mental health problems group 1:1 based on the gender, ethnicity, age and type of work to determine the polymorphisms of 5-HTR2A. Fasting blood samples $(5 \mathrm{~mL})$ were obtained as part of the health examination, and were anonymised. Prior to the health examination, participants were requested to abstain from a high-fat diet and alcohol for 3 days. Blood samples were placed in heparin-anticoagulant tubes and centrifuged at $3000 \mathrm{rpm}$ for $10 \mathrm{~min}$ at $4{ }^{\circ} \mathrm{C}$. Plasma was collected and stored at $-20^{\circ} \mathrm{C}$. Levels of (5-HTR2A) were measured by polymerase chain reaction and restriction fragment length polymorphism (PCR-RFLP).

\subsection{Statistical Analysis}

Two researchers independently recorded the results in the database and a consistency test was conducted. Data were analysed using SPSS for Windows v.17.0 software (SPSS Inc., Chicago, IL, USA). Continuous data were presented as mean \pm standard deviation and compared using the Student's $t$-test. Categorical data were presented as frequencies, and analysed using the chi-squared $\left(\chi^{2}\right)$ test. The $\chi^{2}$ test was used evaluate Hardy-Weinberg equilibrium (HWE). Hardy-Weinberg equilibrium is assumed when observed genotype and allele frequencies between mental health problems and normal group are in equilibrium in a population. To examine the risk associated with mental health problems, odds ratios (OR) and 95\% confidence intervals (CIs) were examined using multivariate logistic regression. $p$-values $<0.05$ were considered statistically significant.

\section{Results}

\subsection{Characteristics of the Participants}

One thousand four hundred and eighty-five questionnaires were distributed, and 1380 were collected and verified to be satisfactory, giving a total retrieval rate of $92.9 \%$. At the end of survey, 556 participants were deemed to exhibit a mental health problems. Thus, the prevalence rate was $40.29 \%$. While a statistically significant difference was found between the mental health problems group and normal group with regard to alcohol consumption $(p=0.009)$, there were no statistically significant differences for all other variables (gender, age group, year, ethnicity, working years, type of work, shift, professional title, educational level, marital status, monthly family income and smoking) $(p>0.05)$ (Table 1).

Table 1. Characteristics of the sample.

\begin{tabular}{|c|c|c|c|c|c|c|c|}
\hline \multirow{2}{*}{\multicolumn{2}{|c|}{ Variables }} & \multicolumn{2}{|c|}{ All Participants (1380) } & \multicolumn{2}{|c|}{ Mental Disorder } & \multirow{2}{*}{$x^{2}$} & \multirow{2}{*}{$p$} \\
\hline & & $n$ & $\%$ & $n$ & $\%$ & & \\
\hline \multirow{2}{*}{ Gender } & Male & 745 & 53.99 & 304 & 40.81 & \multirow{2}{*}{0.179} & \multirow{2}{*}{0.672} \\
\hline & Female & 635 & 46.01 & 252 & 39.69 & & \\
\hline \multirow{2}{*}{ Age group, year } & $\leq 30$ & 199 & 14.42 & 80 & 40.20 & \multirow{2}{*}{0.978} & \multirow{2}{*}{0.522} \\
\hline & $>30$ & 1181 & 85.58 & 476 & 40.30 & & \\
\hline \multirow{2}{*}{ Ethnicity } & Han & 1107 & 80.22 & 446 & 40.29 & \multirow[b]{2}{*}{0.000} & \multirow{2}{*}{0.999} \\
\hline & Minority & 273 & 19.78 & 110 & 40.29 & & \\
\hline \multirow{2}{*}{ Working years } & $\leq 15$ & 412 & 29.86 & 171 & 41.50 & \multirow{2}{*}{0.291} & \multirow{2}{*}{0.589} \\
\hline & $>15$ & 968 & 70.14 & 385 & 39.77 & & \\
\hline \multirow{3}{*}{ Type of work } & Oil transportation & 548 & 39.71 & 228 & 41.60 & \multirow{3}{*}{0.53} & \multirow{3}{*}{0.467} \\
\hline & Extract oil & 405 & 29.35 & 144 & 35.56 & & \\
\hline & Stoker hot note work & 427 & 30.94 & 184 & 43.09 & & \\
\hline \multirow{2}{*}{ Shift } & No & 529 & 38.33 & 249 & 41.57 & \multirow{2}{*}{2.706} & \multirow{2}{*}{0.100} \\
\hline & Yes & 851 & 61.67 & 307 & 39.30 & & \\
\hline \multirow{2}{*}{ Professional title } & Primary and secondary & 776 & 56.23 & 311 & 40.08 & \multirow{2}{*}{0.36} & \multirow{2}{*}{0.548} \\
\hline & Vice-senior and Senior & 604 & 43.77 & 245 & 40.56 & & \\
\hline
\end{tabular}


Table 1. Cont.

\begin{tabular}{|c|c|c|c|c|c|c|c|}
\hline & \multirow{2}{*}{ Variables } & \multicolumn{2}{|c|}{ All Participants (1380) } & \multicolumn{2}{|c|}{ Mental Disorder } & \multirow{2}{*}{$x^{2}$} & \multirow{2}{*}{$p$} \\
\hline & & $n$ & $\%$ & $n$ & $\%$ & & \\
\hline \multirow{2}{*}{$\begin{array}{l}\text { Educational } \\
\text { Level }\end{array}$} & Associate's degree or below & 563 & 40.8 & 222 & 39.43 & \multirow[b]{2}{*}{5.561} & \multirow[b]{2}{*}{0.062} \\
\hline & Bachelor's degree or higher & 817 & 59.2 & 334 & 40.88 & & \\
\hline \multirow{2}{*}{ Marital status } & Single & 121 & 8.77 & 45 & 37.19 & \multirow{2}{*}{0.033} & \multirow{2}{*}{0.855} \\
\hline & Married & 1259 & 91.23 & 511 & 40.58 & & \\
\hline \multirow{2}{*}{$\begin{array}{l}\text { Monthly family } \\
\text { income }\end{array}$} & $\leq 3000$ & 309 & 22.39 & 112 & 36.25 & \multirow{2}{*}{0.72} & \multirow[b]{2}{*}{0.396} \\
\hline & $>3000$ & 1071 & 77.61 & 444 & 41.56 & & \\
\hline \multirow{2}{*}{ Smoking } & Yes & 445 & 32.25 & 175 & 39.32 & \multirow{2}{*}{0.254} & \multirow{2}{*}{0.614} \\
\hline & No & 935 & 67.75 & 381 & 40.75 & & \\
\hline \multirow{2}{*}{ Drinking } & Yes & 624 & 45.22 & 275 & 44.07 & \multirow{2}{*}{6.678} & \multirow{2}{*}{0.009} \\
\hline & No & 756 & 54.78 & 281 & 37.17 & & \\
\hline
\end{tabular}

The participants' total score for mental health was $161.79 \pm 55.27$. The total score as well as the individual scores associated with each of the nine variables were found to be higher than the national norm (Table 2).

Table 2. Assessment results of each component and the total score of Symptom Checklist 90 (SCL-90) $(\bar{\chi} \pm s)$.

\begin{tabular}{lcc}
\hline Variables & SCL-90 Score & Reference Range of China \\
\hline Total score & $161.79 \pm 55.27$ & $129.96 \pm 38.76$ \\
Somatization & $1.92 \pm 0.68$ & $1.37 \pm 0.48$ \\
Obsessive-compulsive & $1.97 \pm 0.70$ & $1.62 \pm 0.58$ \\
Interpersonal sensitivity & $1.79 \pm 0.65$ & $1.65 \pm 0.61$ \\
Depression & $1.80 \pm 0.67$ & $1.50 \pm 0.59$ \\
Anxiety & $1.77 \pm 0.65$ & $1.39 \pm 0.43$ \\
Hostility & $1.76 \pm 0.66$ & $1.48 \pm 0.56$ \\
Phobia & $1.65 \pm 0.66$ & $1.23 \pm 0.41$ \\
Paranoid & $1.72 \pm 0.67$ & $1.43 \pm 0.57$ \\
Psychotic symptoms & $1.65 \pm 0.64$ & $1.29 \pm 0.42$ \\
\hline
\end{tabular}

\subsection{Occupational Stress Variables between the Two Groups}

The degree of Role Overload $((t=5.571, p<0.001)$, Role Insufficiency $(t=4.299, p<0.001)$, Role Ambiguity $(t=2.569, p<0.001)$, Role Boundary $(t=4.640, p<0.001)$, Responsibility $(t=5.097$, $p<0.001)$, Physical Environment $(t=2.663, p<0.001)$, Vocational Strain Reaction $(t=8.765, p<0.001)$, Psychological Strain Reaction $(t=11.220, p<0.001)$, Interpersonal Strain Reaction $(t=7.759, p<0.001)$, and Physical Strain Reaction $(t=13.549, p<0.001)$ were significantly higher in the mental health problems group than in the normal group which are determined as normal condition depending on SCL-90 .

The degree of Recreation $(t=-2.128, p<0.034)$, Social Support $(t=-3.368, p=0.001)$, and Rational Coping ( $p=0.001)$ were significantly lower in the mental health problems group than in the health control group (Table 3). 
Table 3. Comparison of occupational stress variables between the two groups $(\bar{\chi} \pm s)$.

\begin{tabular}{lcccc}
\hline Variables & Mental Health Problems & Normal & $t$ & $p$ \\
\hline Role overload & $28.38 \pm 6.87$ & $26.26 \pm 6.92$ & 5.571 & $<0.001$ \\
Role insufficiency & $31.03 \pm 7.77$ & $29.24 \pm 7.33$ & 4.299 & $<0.001$ \\
Role ambiguity & $32.07 \pm 7.05$ & $31.09 \pm 6.87$ & 2.569 & $<0.001$ \\
Role boundary & $27.80 \pm 6.27$ & $26.17 \pm 6.50$ & 4.640 & $<0.001$ \\
Responsibility & $25.96 \pm 7.13$ & $23.95 \pm 7.18$ & 5.097 & $<0.001$ \\
Physical environment & $32.17 \pm 7.85$ & $31.02 \pm 7.90$ & 2.663 & $<0.001$ \\
Vocational strain & $26.85 \pm 6.27$ & $23.92 \pm 5.96$ & 8.765 & $<0.001$ \\
Psychological strain & $28.25 \pm 6.23$ & $24.34 \pm 6.42$ & 11.220 & $<0.001$ \\
Interpersonal strain & $28.22 \pm 5.47$ & $25.82 \pm 5.78$ & 7.759 & $<0.001$ \\
Physical strain & $27.80 \pm 5.92$ & $23.38 \pm 5.97$ & 13.549 & $<0.001$ \\
Recreation & $27.85 \pm 6.50$ & $28.65 \pm 7.10$ & -2.128 & 0.034 \\
Self-care & $28.73 \pm 6.55$ & $29.18 \pm 8.87$ & -1.214 & 0.225 \\
Social support (SS) & $31.24 \pm 7.29$ & $32.74 \pm 8.62$ & -3.368 & 0.001 \\
Rational coping & $28.94 \pm 6.45$ & $30.23 \pm 7.50$ & -3.304 & 0.001 \\
\hline
\end{tabular}

\subsection{Genetic Balance Check}

The $\chi^{2}$ test was used to evaluate Hardy-Weinberg equilibrium, and suggested a better match between actual values and expected values with regard to 5-HTR2A T102C and A-1438G polymorphism in the sample population $(p>0.05)$. This finding suggests that the research sample population is within the genetic equilibrium state, and is representative of the general population (Table 4).

Table 4. Hardy-Weinberg equilibrium test.

\begin{tabular}{ccccc}
\hline Genotype & Actual Values & Expected Value & $\chi^{2}$ & $p$ \\
\hline T102C & & & & \\
TT & 108 & 120.95 & & \\
TC & 194 & 169.33 & 3.589 & 0.166 \\
CC & 48 & 58.84 & & \\
\hline A-1438G & & & & \\
AA & 73 & 74.61 & & \\
AG & 181 & 174.21 & 0.205 & 0.902 \\
GG & 96 & 99.36 & & \\
\hline
\end{tabular}

3.4. Comparison of T102C, the A-1438G Polymorphism between the Two Groups and the Risk of Mental Health Problems Associated with This Genotype

The results of this study shows a statistically difference between the mental health problems group and the normal group in terms of the T102C, A-1438G polymorphism $(p<0.05)$. There was no statistically difference between the two groups in the allelic gene of T102C and A-1438G $(p>0.05)$ (Table 5)

The association between T102C, A-1438G polymorphism and mental health problems was examined using multivariate logistic regression analysis. With reference to the TT genotype of T102C gene polymorphism, the results revealed that carrying the TC and CC genotypes acts as a protective factor against mental health problems $(\mathrm{OR}=0.455,95 \% \mathrm{CI}=0.269-0.771 ; \mathrm{OR}=0.340$, $95 \% \mathrm{CI}=0.162-0.716)$. With regard to the AA genotype of the A-1438G gene polymorphism, carrying the AG genotype increases the risk of mental health problems in AA genotype by 2.749 times (95\% CI = 1.488-5.080). Carrying the GG genotype increases the risk of mental health problems in AA genotype by 2.654 times (95\% CI = 1.350-5.218). In adjusting Vocational Strain, Psychological Strain, Physical Strain, Social Support, and Rational Coping, T102C gene polymorphism of the TC and CC genotypes reduces the risk of mental health problems $(\mathrm{OR}=0.443,95 \% \mathrm{CI}=0.255-0.770$, 
$\mathrm{OR}=0.360,95 \% \mathrm{CI}=0.164-0.790$ ). With reference to A-1438G gene polymorphism, carrying AG and GG genotypes increases the risk of health problems $(\mathrm{OR} 1=2.729,95 \% \mathrm{CI}=1.433-5.195, \mathrm{OR} 2=2.480$, 95\% CI $=1.221-5.037$ ) (Table 6).

Table 5. The distribution of T102C, A-1438G genotypes and alleles $n$ (\%).

\begin{tabular}{ccccc}
\hline Genotype & Mental Health Problems & Normal & $\chi^{2}$ & $p$ \\
\hline T102C & & & \\
\hline TT & $63(36.00 \%)$ & $45(25.71 \%)$ & \\
TC & $94(53.71 \%)$ & $100(57.14 \%)$ & 6.186 & 0.045 \\
CC & $18(10.29 \%)$ & $30(17.15 \%)$ & & \\
\hline T & $220(62.86 \%)$ & $190(54.29 \%)$ & \multirow{2}{*}{1.726} \\
C & $140(37.14 \%)$ & $148(45.71 \%)$ & & \\
A-1438G & & & \\
\hline AA & $27(15.43 \%)$ & $46(26.28 \%)$ & \\
AG & $99(56.57 \%)$ & $82(46.86 \%)$ & 6.584 \\
GG & $49(28.00 \%)$ & $47(26.86 \%)$ & & \\
\hline A & $153(43.71 \%)$ & $174(49.14 \%)$ & \multirow{2}{*}{1.991} & \\
G & $197(56.29 \%)$ & $181(50.86 \%)$ & & \\
\hline
\end{tabular}

Table 6. The risk of mental health problems.

\begin{tabular}{cccccc}
\hline \multicolumn{2}{c}{ Genotype } & OR (95\% CI) & $p$ & OR * $\mathbf{( 9 5 \% ~ C I ) ~}$ & $p$ \\
\hline T102C & TT & 1 & - & 1 & - \\
& TC & $0.455(0.269-0.771) *$ & 0.027 & $0.443(0.255-0.770) *$ & 0.027 \\
& CC & $0.340(0.162-0.716) *$ & 0.044 & $0.360(0.164-0.790) *$ & 0.043 \\
\hline \multirow{2}{*}{ A-1438G } & AA & 1 & - & 1 & - \\
& AG & $2.749(1.488-5.080) *$ & 0.032 & $2.729(1.433-5.195) *$ & 0.031 \\
& GG & $2.654(1.350-5.218) *$ & 0.031 & $2.480(1.221-5.037) *$ & 0.029 \\
\hline
\end{tabular}

OR adjusted for the Vocational Strain, Psychological Strain, Physical Strain, Social Support and Rational Coping; $* p<0.05$.

\section{Discussion}

This study investigated the relationship between occupational stress, 5-HT2A receptor polymorphisms and mental health in petroleum workers in the Xinjiang arid desert. As a complex and chronic disease, mental disorder is affected by many factors. Some studies [40-42] have found that higher stress levels were more prevalent among females than males. However, this current research found that incidence of mental health problems is no statistically significant differences with regard to gender differences. This finding may be attributed to the unique work environment, the various tasks carried out by employees as well as the diverse methods that may be used for mental health screening.

The participants' alcohol consumption proved to be a statistically significant variable in mental health problems. Abstinence from alcohol consumption was found to be a protective factor against mental health problems. This finding is consistent with the results of Lacey et al. [43]. Petroleum workers spend prolonged periods of time in a unique environment, and are often subjected to noise and heavy workloads. With few recreational activities available, these employees may be attracted to consuming alcohol in an effort to relieve stress, which only increases alcohol dependency, inevitably leading to the onset of depression, anxiety and other psychological disorders.

To determine the incidence of mental health problems, this current study used a total score of $>160$ points, as measured using the SCL-90-R. The survey featured 556 participants. The incidence rate was found to be $40.29 \%$. The total score as measured using the SCL-90-R was $161.79+55.27$ points. While this result is higher than the total score found in the Zhang et al. study [44] which examined the 
mental health of petroleum workers, this score is also higher than the national norm. Thus, petroleum workers exhibit a higher incidence of mental health problems. This finding may be related to long-term contact with occupationally harmful factors encountered in the course of the work such as bad weather, dust, noise, and crude oil. In addition, emergencies and unforeseen factors may occur without warning. These factors may contribute to the onset and development of mental health problems in petroleum workers, such as anxiety, loneliness, agitation, and may increase the risk of workplace accidents.

Significant differences were found between the mental health problems group and normal group with regard to work-related stressors and personal stress. This results suggests that these variables may have positive correlation with the incidence of mental health problems. Relevant epidemiological studies have highlighted stress as a risk factor for mental health problems [45], showing a strong correlation between stress and mental health problems. Progressively high levels of stress correlate with an increased risk of developing a mental health problems [46]. Statistically significant differences were found between the two groups with regard to Recreation, Social Support and Rational Coping, suggesting that this factor plays a significant role in an individual's ability to cope with mental health problem. This results offer an insight into the factors associated with mental health, and underscore the need to establish policies to minimise occupational stress in order to protect the health of petroleum workers in arid deserts.

The results of this current study revealed a statistically significant difference between the mental health problems group and normal groups with regard to the T102C and A-1438G genotypes, suggesting that T102C and A-1438G genotypes of the 5-HTR2A genewere associated with the incidenceof mental health problems. Although this finding was consistent with the results of some previous research $[47,48]$, other studies $[49,50]$ obtained the opposite result, which may be attributed to the use of different sample populations or the influence of regional differences. Logistic regression analysis was used to examine the relationship between T102C and A-1438G genotypes and the risk of mental health problems. With regard to the T102C gene, and after having adjusted for some occupational stress factors, the results suggest that carrying the TC and CC genotype as opposed to the TT genotype may reduce the risk of mental health problems. Furthermore, the $C$ allele may be a protective factor against mental health problems. The Zhang et al. study [51] examined the relationship between 5-HT2A receptor gene T102C polymorphism and grey matter density in patients with depression. The results revealed that the $\mathrm{C}$ allele may be a mediating factor as alleles within the human brain structure may increase susceptibility to regional depression. However, in normal brain structure, $C$ alleles exert no obvious effect. Similarly, the Chen et al. study [52] concluded that the $C$ allele is a protective factor against depression following a stroke. With regard to the A-1438G gene, carrying AG and GG genotypes as opposed to the AA genotype may increase the risk of mental health problems. Zhao et al. [24] concluded that the risk of carrying GG genotype is as 1.20 times high as that of AA + AG genotype (CI = 1.02-1.43). Additionally, a study conducted by Kim et al. [53] obtained a similar conclusion. These findings suggest that the T102C C genotype and A-1438G G genotype may, to a certain extent, affect mental health problems, and that factors inherent to occupational stress may furthermore influence the onset and development of mental illness.

There were some limitations to the present study. Due to the descriptive study design, causal relationship cannot be established in general. Second, the sample size was small. Participants were recruited from a single administration bureau in Xinjiang, which might not be representative of the entire population of petroleum workers in China. Third, we used a self-report questionnaire to measure the prevalence of mental health problems, which may have yielded recall/report bias. Finally, this study investigated a minimal number of polymorphisms that are correlated with stress. However, it is possible that other polymorphisms of the 5-HTR2A gene influence susceptibility to mental health problems. In the future, the researchers aim to undertake a cohort study to investigate occupational stress-induced mental problems in individuals exposed to the Xinjiang arid desert environment. A study of this nature could provide additional evidence that may highlight the importance of understanding occupational stress and mental health problems in petroleum workers. 


\section{Conclusions}

In conclusion, the results of this study revealed a high incidence rate of mental health problems in petroleum workers stationed in the arid desert, and furthermore suggested a strong correlation between occupational stress and mental health problems. TC and CC genotypes of 5-HTR2A were found to be protective factors against the onset and development of mental health problems, whereas AG and GG genotypes were identified as risk factors.

Acknowledgments: This study was funded by the National Nature Science Foundation of China (Grant No.: 81460489).

Author Contributions: Ting Jiang, Hua Ge and Jiwen Liu contributed to the conception and design; Ting Jiang, Rui Han and Rong Li contributed to the acquisition of data; Ting Jiang, Hua Ge and Jian Sun analysed and interpreted the data, and drafted the article. All authors have given their final approval of the version to be published.

Conflicts of Interest: The authors declare no conflict of interest.

\section{References}

1. Weinberg, A.; Creed, F. Stress and psychiatric disorder in healthcare professionals and hospital staff. Lancet 2000, 355, 533-537. [CrossRef]

2. Martinez, M.C.; do Rosário Dias de Oliveira Latorre, M.; Fischer, F.M. A cohort study of psychosocial work stressors on work ability among Brazilian hospital workers. Am. J. Ind. Med. 2015, 58, 795-806. [CrossRef] [PubMed]

3. Ding, N.; Berry, H.L.; O'Brien, L.V. One-year reciprocal relationship between community participation and mental wellbeing in Australia: A panel analysis. Soc. Sci. Med. 2015, 128, 246-254. [CrossRef] [PubMed]

4. De Lange, A.H.; Taris, T.W.; Kompier, M.A.; Houtman, I.L.; Bongers, P.M. The very best of the millennium: Longitudinal research and the demand-control-(support) model. J. Occup. Health Psychol. 2003, 8, 282-305. [CrossRef] [PubMed]

5. Inoue, M.; Tsurugano, S.; Yano, E. Job stress and mental health of permanent and fixed-term workers measured by effort-reward imbalance model, depressive complaints, and clinic utilization. J. Occup. Health 2011, 53, 93-101. [CrossRef] [PubMed]

6. Strazdins, L.; D'Souza, R.M.; Clements, M.; Broom, D.H.; Rodgers, B.; Berry, H.L. Could better jobs improve mental health? A prospective study of change in work conditions and mental health in mid-aged adults. J. Epidemiol. Community Healh 2011, 65, 529-534. [CrossRef] [PubMed]

7. Marchand, A.; Demers, A.; Durand, P. Do occupation and work conditions really matter? A longitudinal analysis of psychological distress experiences among Canadian workers. Sociol. Health Illn. 2005, 27, 602-627. [CrossRef] [PubMed]

8. Rugulies, R.; Bültmann, U.; Aust, B.; Burr, H. Psychosocial work environment and incidence of severe depressive symptoms: Prospective findings from a 5-year follow-up of the Danish work environment cohort study. Am. J. Epidemiol. 2006, 163, 877-887. [CrossRef] [PubMed]

9. Zablotsky, B.; Bradshaw, C.P.; Stuart, E.A. The association between mental health, stress, and coping supports in mothers of children with autism spectrum disorders. J. Autism Dev. Disord. 2013, 43, 1380-1393. [CrossRef] [PubMed]

10. Wang, L.J; Chen, C.K.; Hsu, S.C.; Lee, S.Y.; Wang, C.S.; Yeh, W.Y. Active job, healthy job? Occupational stress and depression among hospital physicians in Taiwan. Ind. Health 2011, 49, 173-184. [CrossRef] [PubMed]

11. Cho, H.S.; Kim, Y.W.; Park, H.W.; Lee, K.H.; Jeong, B.G.; Kang, Y.S.; Park, K.S. The relationship between depressive symptoms among female workers and job stress and sleep quality. Ann. Occup. Environ. Med. 2013, 25, 12. [CrossRef] [PubMed]

12. Cuijpers, P.; Smit, F. Subthreshold depression as a risk indicator for major depressive disorder: A systematic review of prospective studies. Acta Psychiatr. Scand. 2004, 109, 325-331. [CrossRef] [PubMed]

13. An, S.J.; Chung, Y.K.; Kim, B.H.; Kwak, K.M.; Son, J.-S.; Koo, J.; Ju, Y.-S.; Kwon, Y.-J. The effect of organizational system on self-rated depression in a panel of male municipal fire fighters. Ann. Occup. Environ. Med. 2015, 27, 158-168. [CrossRef] [PubMed] 
14. Arnett, M.G.; Muglia, L.M.; Laryea, G.; Muglia, L.J. Genetic Approaches to Hypothalamic-Pituitary-Adrenal Axis Regulation. Neuropsychopharmacology 2016, 41, 245-260. [CrossRef] [PubMed]

15. Juster, R.P.; Mcewen, B.S.; Lupien, S.J. Allostatic load biomarkers of chronic stress and impact on health and cognition. Neurosci. Biobehav. Rev. 2010, 35, 2-16. [CrossRef] [PubMed]

16. Kuepper, Y. Hypothalamic-pituitary-adrenal axis. In International Encyclopedia of the Social E Behavioral Sciences, 2nd ed.; Elsevier: Amsterdam, The Netherlands, 2015; pp. 476-481.

17. Harris, A.; Seckl, J. Glucocorticoids, prenatal stress and the programming of disease. Horm. Behav. 2011, 59, 279-289. [CrossRef] [PubMed]

18. Van Prang, H.M. Crossroads of corticotrophin releasing hormone, corticosteroids and monoamines. About a biological interface between stress and depression. Neurotox. Res. 2002, 4, 531-555.

19. Yoon, H.K.; Kim, Y.K. TPH2-703G/T SNP may have important effect onsusceptibility to suicidal behavior in major depression. Prog. Neuropsychopharmacol. Biol. Psychiatry 2009, 33, 403-409. [CrossRef] [PubMed]

20. Norton, N.; Owen, M.J. HTR2A: Association and expression studies in neuropsychiatric genetics. Ann. Med. 2005, 37, 121-129. [CrossRef] [PubMed]

21. Nugent, N.R.; Tyrka, A.R.; Carpenter, L.L.; Price, L.H. Gene-environment interactions: Early life stress and risk for depressive and anxiety disorders. Psychopharmacology 2011, 214, 175-196. [CrossRef] [PubMed]

22. Lin, C.X.; Hu, Z.; Yan, Z.M.; Li, W.; Chen, Y.S.; Zhao, J.H.; Zhang, L.Q.; Zhao, B.; Zhong, W.T.; Feng, D. Association between HTR2A T102C polymorphism and major depressive disorder: A meta-analysis in the Chinese population. Int. J. Clin. Exp. Med. 2015, 8, 20897-20903. [PubMed]

23. Guo, H.; Ren, Y.; Zhao, N.; Wang, Y.; Li, S.; Cui, H.; Zhang, S.; Zhang, J. Synergistic effect of 5-HT2A receptor gene and MAOA gene on the negative emotion of patients with depression. Clin. Physiol. Funct. Imaging 2014, 34, 277-281. [CrossRef] [PubMed]

24. Zhao, X.; Sun, L.; Sun, Y.H.; Ren, C.; Chen, J.; Wu, Z.Q.; Jiang, Y.H.; Lv, X.L. Association of HTR2A T102C and A-1438G polymorphisms with susceptibility to major depressive disorder: A meta-analysis. Neurol. Sci. 2014, 35, 1857-1866. [CrossRef] [PubMed]

25. Petit, A.C.; Quesseveur, G.; Gressier, F.; Colle, R.; David, D.J.; Gardier, A.M.; Ferreri, F.; Lépine, J.P.; Falissard, B.; Verstuyft, C.; et al. Converging translational evidence for the involvement of the serotonin2A receptor gene in major depressive disorder. Prog. Neuropsychopharmacol. Biol. Psychiatry 2014, 54, 76-82. [CrossRef] [PubMed]

26. Serretti, A.; Calati, R.; Giegling, I.; Hartmann, A.M.; Möller, H.J.; Colombo, C.; Rujescu, D. 5-HT2A SNPs and the temperament and character inventory. Prog. Neuropsychopharmacol. Biol. Psychiatry 2007, 31, 1275-1281. [CrossRef] [PubMed]

27. Ljoså, C.H.; Tyssen, R.; Lau, B. Perceived mastery of work among shift workers in the Norwegian offshore petroleum industry. Ind. Health 2013, 51, 145-153. [CrossRef] [PubMed]

28. Liu, X.D.; Li, J.G.; Lian, Y.L. Research on Mental Fatigue of Soldiers in the Arid Desert. Hosp. Adm. J. Chin. People's Lib. Army 2011, 19, 124-126. (In Chinese).

29. Béjean, S.; Sultan-Taïeb, H. Modeling the economic burden of diseases imputable to stress at work. Eur. J. Health Econ. 2015, 6, 16-23. [CrossRef] [PubMed]

30. Rao, J.V.; Chandraiah, K. Occupational stress, mental health and coping among information technology professionals. J. Occup. Environ. Med. 2012, 16, 22-26. [CrossRef] [PubMed]

31. Wu, H.; Liu, L.; Wang, Y.; Gao, F.; Zhao, X.; Wang, L. Factors associated with burnout among Chinese hospital doctors: A cross-sectional study. BMC Public Health 2013, 13, 786. [CrossRef] [PubMed]

32. Lian, Y.; Gu, Y.; Han, R.; Jiang, Y.; Guan, S.; Xiao, J.; Liu, J. Effect of Changing Work Stressors and Coping Resources on Psychological Distress. J. Occup. Environ. Med. 2016, 58, 256-263. [CrossRef] [PubMed]

33. Jiang, Y.; Tang, J.; Li, R.; Zhao, J.; Song, Z.; Ge, H.; Lian, Y.; Liu, J. Effect of 5-HT2A Receptor Polymorphisms, Work Stressors, and Social Support on Job Strain among Petroleum Workers in Xinjiang, China. Int. J. Environ. Res. Public Health 2016, 13, 1258. [CrossRef] [PubMed]

34. Chen, S.; Li, L. Re-testing reliability, validity and norm applicability of SCL-90. Chin. J. Nerv. Ment. Dis. 2003, 29, 323-327.

35. Wang, X.D. Mental Health Rating Scale Manual (Supplement); Chinese Mental Health Magazine: Beijing, China, 1993; pp. 31-36.

36. Shan, M.H. Measuring the level of mental health by correctly using SCL-90 and 16PF measurement. Chin. Mental Health J. 1998, 12, 81-82. 
37. Li, J.; Lan, Y.J.; Wang, Z.M.; Wang, M.Z.; Liu, G.Q. The test of occupational stress inventory revised edition. Chin. J. Ind. Occup. Dis. 2001, 19, 190-193.

38. Wu, H.; Zhao, Y.; Wang, J.; Wang, L. Factors associated with occupational stress among Chinese doctors: A cross-sectional survey. Int. Arch. Occup. Environ. Health 2010, 83, 155-164. [CrossRef] [PubMed]

39. Yang, X.; Wang, L.; Ge, C.; Hu, B.; Chi, T. Factors associated with occupational strain among Chinese teachers: A cross-sectional study. Public Health 2011, 125, 106-113. [CrossRef] [PubMed]

40. Sultan-Taïeb, H.; Chastang, J.F.; Mansouri, M.; Niedhammer, I. The annual costs of cardiovascular diseases and mental disorders attributable to job strain in France. BMC Public Health 2013, 13, 748. [CrossRef] [PubMed]

41. Kelly, B.D.; O'Callaghan, E.; Waddington, J.L.; Feeney, L.; Browne, S.; Scully, P.J.; Clarke, M.; Quinn, J.F.; McTigue, O.; Morgan, M.G.; et al. Schizophrenia and the city: A review of literature and prospective study of psychosis and urban city in Ireland. Schizophr. Res. 2011, 116, 75-89. [CrossRef] [PubMed]

42. Dupere, V.; Perkins, D.D. Community types and mental health: A multilevel study of local environment stress and coping. Am. J. Community Psychol. 2007, 39, 107-118. [CrossRef] [PubMed]

43. Lacey, K.K.; Sears, K.P.; Crawford, T.V.; Matusko, N.; Jackson, J.S. Relationship of social and economic factors to mental disorders among population based samples of Jamaicans and Guyanese. BMJ Open 2016, 6, e012870. [CrossRef] [PubMed]

44. Zhang, Q.; Zhou, D.-L.; Lan, Y.-J. Status research on mental health of oil drilling workers. J. North Sichuan Med. Coll. 2014, 29, 39-43. (In Chinese)

45. Klein, J.P.; Moritz, S. On the relevance of mental imagery beyond stress-related psychiatric disorders. Front. Psychiatr. 2014, 7, 75-77. [CrossRef] [PubMed]

46. Yambo, T.; Johnson, M. An integrative review of the mental health of partners of veterans with combat-related posttraumatic stress disorder. J. Am. Psychiatr. Nurses Assoc. 2014, 17, 31-41. [CrossRef] [PubMed]

47. Wu, Y.; Liu, H.B.; Ding, M.; Liu, J.N.; Zhu, X.F.; Gu, J.H.; Lu., G. Association between the -1438G/A and T102C polymorphisms of 5-HT2A receptor gene and obstructive sleep apnea: A meta-analysis. Mol. Biol. Rep. 2013, 40, 6223-6231. [CrossRef] [PubMed]

48. Choi, M.J.; Lee, H.J.; Lee, H.J.; Ham, B.J.; Cha, J.H.; Ryu, S.H.; Lee, M.S. Association between major depressive disorder and the $-1438 \mathrm{~A} / \mathrm{G}$ polymorphism of the serotonin $2 \mathrm{~A}$ receptor gene. Neuropsychobiology 2004, 49, 38-41. [CrossRef] [PubMed]

49. Yildiz, S.H.; Akilli, A.; Bagcioglu, E.; Ozdemir Erdogan, M.; Coskun, K.S.; Alpaslan, A.H.; Subasi, B.; Arikan Terzi, E.S. Association of schizophrenia with T102C (rs6313) and 1438 A/G (rs6311) polymorphisms of HTR2A gene. Acta Neuropsychiatr. 2013, 25, 342-348. [CrossRef] [PubMed]

50. Tencomnao, T.; Thongrakard, V.; Phuchana, W.; Sritharathikhun, T.; Suttirat, S. No relationship found between $-1438 \mathrm{~A} / \mathrm{G}$ polymorphism of the serotonin $2 \mathrm{~A}$ receptor gene (rs6311) and major depression susceptibility in a northeastern Thai population. Genet. Mol. Res. 2010, 9, 1171-1176. [CrossRef] [PubMed]

51. Zhang, J.; Liu, H.; Yao, Z.; Lu, Q. Association study on 5-HT 2A receptor gene T102C polymorphism and the concentration of gray matter in patients with major depressive disorder. Chin. J. Nerv. Men Dis. 2011, 37, 210-213. (In Chinese)

52. Chen, C.; Liu, Z.-H.; Chen, A.-M.; Zhao, L.-X. Association between polymorphism of 5-hydroxy tryptamine 2A receptor T102C gene and poststroke depression. Chin. J. Neuromed. 2011, 10, 1119-1121. (In Chinese)

53. Kim, J.M.; Stewart, R.; Bae, K.Y.; Kim, S.W. Serotonergic and BDNF genes and risk of depression after stroke. J. Affect. Disord. 2012, 136, 1-8. [CrossRef] [PubMed]

(C) 2017 by the authors. Licensee MDPI, Basel, Switzerland. This article is an open access article distributed under the terms and conditions of the Creative Commons Attribution (CC BY) license (http://creativecommons.org/licenses/by/4.0/). 